\title{
Daya Gabung Beberapa Varietas Padi (Oryza sativa L.) pada Persilangan Dialel Menggunakan Metode Griffing II
}

\author{
Combining Power of Several Rice Varieties (Oryza sativa L.) \\ in Diallel Crosses Using the Griffing Method II
}

\author{
Anak Agung Ketut Sudharmawan*, Baiq Erna Listiana, Sofi Rianti \\ Agroekoteknologi/Budidaya Pertanian, Fakultas Pertanian, Universitas Mataram \\ *Corresponding Author Email: agungsudharmawan@gmail.com
}

Manuscript received: 08-12-2020. Accepted: 25-10-2021

\begin{abstract}
ABSTRAK
Persilangan dialel merupakan metode yang banyak dilakukan untuk mengetahui kemampuan menggabung setiap individu sehingga dapatdiketahui tetua-tetua yang berpotensi untuk digunakan dalam program persilangan untuk merakit varietas berdaya hasil tinggi. Percobaan ini bertujuan untuk mengetahui daya gabung hasil persilangan dialel beberapa varietas tanaman padi menggunakan metode Griffing II, dilaksanakan di lahan percobaan Fakultas Pertaniaan Universitas Mataram di Desa Nyiur Lembang Kecamatan Narmada, Kabupaten Lombok Barat, pada bulan Februari sampai dengan Juli 2019. Percobaan ini menggunakan metode ekperimental yang dilaksanakan di lapang. Bahanbahan yangdigunakan dalam percobaan ini adalahempat tetua yaitu varietas IPB 3S, varietas Situ Patenggang, Inpari 32 dan Galur G11 serta fenotipe hasil persilangan antar keempat tetua. Hasil percobaan menunjukkan bahwa efek daya gabung umum dan daya gabung khusus untuk semua karakter yang di amati (tinggi tanaman, jumlah anakan produktif, jumlah anakan non produktif, panjang malai, jumlah gabah berisi, jumlah gabah hampa dan berat 100 butir) berbeda nyata, kecuali pada efek daya gabung umum karakterjumlah anakan non produktif menunjukkan tidak berbeda nyata. Hasil analisis daya gabung empat tetua bernilai positif, sehingga dapat dikatakan ke empat tetua akan mendapatkan hasil yang bagus apabila disilangkan dengan sejumlah genotipe lain.
\end{abstract}

Kata kunci: tetua; F1; fenotipe; genotype

\begin{abstract}
Diallel crossing is a method that is widely used to determine the ability to combine each individual so that it can identify the potential elders to be used in crossbreeding programs to assemble high yielding varieties. This experiment aims to determine the combining power of dialelic crosses of several varieties of rice using the Griffing II method, carried out in the experimental field of the Faculty of Agriculture, Mataram University in Nyiur Lembang Village, Narmada District, West Lombok Regency, from February to July 2019. This experiment uses the method experiments carried out in the field. The materials used in this experiment were four parents, namely IPB $3 \mathrm{~S}$ variety, Situ Patenggang variety, Inpari 32 and G11 strain and the phenotype of the cross between the four parents. The experimental results showed that the effects of general affinity and special affinity for all observed characters (plant height, number of productive tillers, number of non-productive tillers, panicle length, number of filled grain, number of empty grain and weight of 100 grains) were significantly different, except on the effect of general affinity for the number of non-productive tillers
\end{abstract}


showed no significant difference. The results of the combined power analysis of the four elders were positive, so it can be said that the four elders would get good results when crossed with a number of other genotypes.

Keyword: elder; F1; phenotype; genotype

\section{PENDAHULUAN}

Padi merupakan komoditas pertanian yang sangat penting terutama di wilayah Asia Timur. Sembilan puluh persen produksi beras dunia dihasilkan oleh negara-negara di Asia, salah satunya adalah Indonesia. Menurut Purwanto (2018), produksi padi pada tahun 2017 mencapai 80,3 juta ton. Peningkatan tersebut sebagai akibat dari peningkatan produksi padi yang sangat signifikan yaitu sebesar 3,13\% (wilayah pulau Jawa) dan 7,01\% (luar pulau Jawa). Perkiraan surplus dalam produksi beras sebesar 13,03 juta ton. Berbagai kelebihan dimiliki oleh padi beras merah yaitu mengandung berbagai kandungan gizi dan kandungan antosianin yang diyakini dapat mencegah berbagai penyakit, seperti kanker, kolestrol, dan jantung, disamping itu umumnya padi lokal memiliki keunggulan genetik tertentu.

Persilangan dialel merupakan salah satu rancangan persilangan yang banyak dipergunakan dalampemuliaan tanaman. Untuk merakit varietas yang berdaya hasil tinggi, diperlukan informasi daya gabung tetua, baik daya gabung umum (DGU) maupun daya gabung khusus (DGK).Persilangan dialel merupakan metode yang banyak dilakukan untuk mengetahui kemampuan menggabung setiap individu dalam persilangan.Metode ini digunakan untuk mengetahui tetua-tetua yang berpotensi untuk digunakan dalam program persilangan untuk menghasilkan varietas unggul baru (Malik et al., 2004).Daya gabung ini dianalisis setelah dilakukan persilangan dialel lengkap. Persilangan dialel adalah sebuah setpersilangan yang dilakukan melibatkan tetua dalam seluruh kombinasi persilangan yang mungkin (Singh \& Chaudary 1979).

Metode persilangan dialel dapat digunakan untuk mengevaluasi potensi genetik suatu galur pada saat disilangakan dengan galur lainnya. Interpretasi analisis dialel hanya berlaku pada populasi asal tetua yang digunakan (model II). Terdapat empat jenis rancangan persilangan dialrl yang umum digunakan (Griffing, 1956) yaitu: 1. Metode I: persilangan dialel penuh dengan resiprok dan galur tetuanya (p2). 2. Metode II: persilangan dialel sebagian dengan galur tetua tanpa resiprok. 3. Metode III: persilangan dialel penuh dengan resiprok tanpa galur tetua. 4. Metode IV: persilangan dialel sebagian sebagian tanpa galur tetua dan resiprok. Beberapa asumsi yang harus tepenuhi dalam menggunakan rancangan persilangan dialel yaitu (i) segregasi diploid pada tetua, (ii) tidak ada perbedaan antara persilangan dengan resiproknya, (iii) tetua yang digunakan homozigot, (iv) dua alel per lokus, (v) tidak ada interaksi antaralel, dan (vi) gen-gen yang terdistribusi pada tetua tidak saling berkorelasi (Nassar, 1964). Berdasarkan uraian diatas, maka penelitian yang berjudul “Analisis Daya Gabung Hasil Persilangan Dialel beberapa Varietas Padi (Oryza sativa L.) Menggunakan Metode Griffing" telah dilakukan sebagai langkah awal dalam penelitian pemuliaan tanaman. 


\section{Bahan}

\section{METODE}

Bahan-bahan yangdigunakan dalam percobaan ini yaitu materi genetik empat tetua tanaman padi dan genotipe hasil persilangan antar keempat tetua, yaitu varietas IPB 3S, varietas Situ Patenggang, Inpari 32 dan Galur 11, Atonik, Cruiser, pupuk Urea danNPK.

\section{Sintesis Tahap 1}

Penelitian inidilaksanakan di Lahan Percobaan Pertanian Universitas Mataram yang berada di Desa Nyiur Lembang Narmada, Kabupaten Lombok Barat, Nusa Tenggara Barat. Penelitian dilaksanakan pada bulan Februari sampai Juli 2019.Percobaan ini dilaksanakan menggunakan Analisis Dialel 2 dengan Rancangan Acak Kelompok (RAK).

\section{Sintesis tahap 2}

Penelitian persilangan dialel ini menggunakan metode Griffing (dialel 2). Galat dapat diduga dengan menggunakan Rancangan Acak Kelompok (RAK) dengan faktor tunggal, yaitu genotipe. Data yang dianalisis menggunakan metode Griffing. Analisis yang digunakan adalah sebagai berikut:

- Analisis ragam, data diuji dengan uji F untuk melihat perbedaan di antara genotipe pesilangan. Data diolah dengan aplikasi Qbasic.

- Pendugaan ragam dan peragam, nilai ragam dan peragaman dapat diduga dengan cara, data dirata-ratakan berdasarkan ulangan dan resiproknya membentuk tabel setengah dialel.

- Analisis daya gabung, model statistik yang di gunakan adalah:

$Y_{i j}=m+g_{i}+g_{j}+s_{i j}+1 / b c \sum \sum_{i j k l}$

Keterangan:

$Y_{i j k l}=$ nilai tengah genotype $\mathrm{i} \mathrm{x} \mathrm{j}$

$\mathrm{m}=$ nilai tengah umum

$g_{i}$ = daya gabung umum (DGU) tetua ke-i

$g_{j}$ = daya gabung khusus (DGK) tetua ke-j

$s_{i j}=$ pengaruh daya gabung khusus (DGK)

$1 / b c \sum \sum_{i j k l} \quad=$ nilai tengah pengariuh galat

- Daya Gabung Umum (General Combining Ability)

$g_{i}=\frac{1}{n+2}\left[\sum\left(y_{i}+y_{i i}\right)-\frac{2}{n} y ..\right]$

Keterangan :

$g_{1}$ = Daya gabung umum

$\mathrm{n} \quad=$ Jumlah galur (genotipe tetua)

$Y_{i} \quad=$ Jumlah nilai tengah persilangan genotipe ke-i

$Y_{. j} \quad=$ Jumlah nilai tengah selfing genotipe ke-j

$Y_{\ldots} \quad=$ Total nilai tengah genotipe

- Daya Gabung Khusus (Spesific Combinatioon Ability)

$S_{i j}=Y_{I J}-\frac{1}{n+2}\left(y_{i .+} y_{i i}+y_{. j}+y_{j j}\right)+\frac{1}{(n+1)(n+2)} Y_{. .}$

Keterangan:

$S_{i j}=$ Daya gabung khusus galur murni ke-i

$Y_{. i}=$ Jumlah dan rata-rata persilangan ke-i 
$Y_{i i}=$ Rata-rata persilangan ke- $\mathrm{i} \mathrm{x} \mathrm{i}$

$Y=$ Jumlah total

$Y_{. j}=$ Total rata-rata persilangan ke $\mathrm{j}$

$Y_{i j}=$ Rata-rata persilangan $\mathrm{i} \mathrm{x} \mathrm{j}$

$Y_{j j}=$ Rata-rata persilangan $\mathrm{j} \mathrm{x} \mathrm{j}$

\section{HASIL DAN PEMBAHASAN}

Hasil analisis keragaman (Tabel 1) menunjukkan bahwa data analisis karakter untuk tinggi tanaman, jumlah anakan produktif, jumlah anakan non produktif, panjang malai, gabah berisis, gabah hampa dan berat 100 butir. Hal ini mengindikasikan adanya gen-gen di luar inti yang berpengaruh pada karakter sehingga keragaman suatu persilangan tidak akan sama (Sudharmawan et al., 2007).

Tabel 1. Nilai F DGU dan DGK untuk Semua Karakter

\begin{tabular}{|c|c|c|c|c|c|c|c|}
\hline \multirow{2}{*}{ SK } & \multicolumn{7}{|c|}{$\mathrm{F}$} \\
\hline & TT & JAP & JANP & PM & JGB & JGH & B100 \\
\hline DGU & $15.81 *$ & $10.93^{*}$ & 0.21 & $8.80 *$ & $10.40 *$ & $15.13^{*}$ & $9.80 *$ \\
\hline DGK & $18.54 *$ & $22.73^{*}$ & $4.31 *$ & $17.81^{*}$ & $19.40^{*}$ & $12.59 *$ & $18.07 *$ \\
\hline
\end{tabular}

Keterangan:

SK $=$ Sumber Keragaman, $\mathrm{F}=$ Nilai hitung, TT $=$ Tinggi Tanaman, $\mathrm{JAP}=$ jumlah anakan produktif, $\mathrm{JANP}=$ jumlah anakan non produkif, $\mathrm{PM}=$ panjang malai, $\mathrm{JGB}=$ jumlah gabah berisi, JGH= jumlah gabah hampa, B100= berat 100 butir.

Karakter tinggi tanaman, jumlah anakan produktif, jumlah anakan non produktif, panjang malai, gabah berisi, gabah hampa dan berat 100 biji termasuk karakter kuantitatif yang dikendalikan oleh banyak gen, masing-masing gen berpengaruh kecil terhadap ekspresi suatu karakter (Trustinah, 1997). Nilai duga DGU dan DGK untuk semua karakter yang di amati (Tabel 2) menunjukkan bahwa karakter tinggi tanaman, jumlah anakan produktif (Tabel 3), jumlah anakan non produktif (Table 4), panjang malai (Tabel 5), jumlah gabah berisi (Tabel 6), jumlah gabah hampa (Tabel 7) dan berat 100 butir (Tabel 8).

Tabel 2. Nilai duga DGU dan DGK karakter tinggi tanaman

\begin{tabular}{lllll}
\hline TETUA & G11 & IPB & IP & SP \\
\hline G11 & 107.2 & 110.56 & 106.3 & 106.7 \\
IPB & & 113.8 & 98.4 & 87.5 \\
IP & & & 82.3 & 80.5 \\
SP & & & & 86.3 \\
\hline
\end{tabular}

Tabel 3. Nilai duga DGU dan DGK karakter jumlah anakan produktif

\begin{tabular}{lllll}
\hline TETUA & G11 & IPB & IP & SP \\
\hline G11 & 15 & 8.22 & 9 & 17 \\
IPB & & 7.6 & 8.6 & 10.5 \\
IP & & 11 & 9.5 \\
SP & & & 13.3 \\
\hline
\end{tabular}


Tabel 4. Nilai duga DGU dan DGK karakter jumlah anakan non produktif

\begin{tabular}{lllll}
\hline TETUA & G11 & IPB & IP & SP \\
\hline G11 & 2 & 1.44 & 1.33 & 1.2 \\
IPB & & 1.44 & 1.6 & 2 \\
IP & & & 2.4 & 3 \\
SP & & & & 2.1 \\
\hline
\end{tabular}

Tabel 5. Nilai duga DGU dan DGK karakter panjang malai

\begin{tabular}{lllll}
\hline TETUA & G11 & IPB & IP & SP \\
\hline G11 & 26.3 & 25.44 & 25 & 25.9 \\
IPB & & 30.4 & 28.2 & 25.25 \\
IP & & & 23.3 & 24.5 \\
SP & & & 24.8 \\
\hline
\end{tabular}

Tabel 6. Nilai duga DGU dan DGK karakter jumlah gabah berisi

\begin{tabular}{lllll}
\hline TETUA & G11 & IPB & IP & SP \\
\hline G11 & 106.5 & 105.67 & 109.7 & 107.9 \\
IPB & & 207.6 & 143 & 134.75 \\
IP & & & 134.1 & 122 \\
SP & & & & 125.5 \\
\hline
\end{tabular}

Tabel 7. Nilai duga DGU dan DGK karakter jumlah gabah hampa

\begin{tabular}{lllll}
\hline TETUA & G11 & IPB & IP & SP \\
\hline G11 & 10.5 & 11.22 & 6.67 & 11 \\
IPB & & 31.2 & 12.4 & 12.75 \\
IP & & & 16.4 & 8 \\
SP & & & & 7.2 \\
\hline
\end{tabular}

Tabel 8. Nilai duga DGU dan DGK karakter berat 100 butir

\begin{tabular}{lllll}
\hline TETUA & G11 & IPB & IP & SP \\
\hline G11 & 2.741 & 2.704 & 2.453 & 2.724 \\
IPB & & 2.695 & 2.522 & 2.457 \\
IP & & & 2.357 & 2.405 \\
SP & & & & 2.373 \\
\hline
\end{tabular}

Keterangan: angka miring ialah nilai DGU pada kolom atau garis yang sama.

\section{PEMBAHASAN}

Hasil analisis Dialel dua metode Griffing efek DGU dan DGK terhadap karakter yang diamati (Tinggi tanaman, jumlah anakan produktif, jumlah anakan non produktif, panjang malai, jumlah gabah berisi, jumlah gabah hampa dan berat 100 butir) (Tabel 1). Untuk efek DGU dari semua karakter tersebut hanya jumlah anakan non produktif saja yang tidak nyata sedangkan untuk DGK semua karakternya berpengaruh nyata. Pengaruh DGU dan DGK yang nyata menunjukkan bahwa komponen ragam genetik yang berpengaruh terhadap penampilan karakter-karakter tersebut adalah ragam aditif (Aliu et al., 2008). Nilai DGU yang lebih besar dari nilai DGK pada karakter (Jumlah gabah hampa) menunjukkan ragam aditif lebih dominan dari ragam non aditif. Ragam genetik aditif merupakan penyebab 
utama kesamaan diantara kerabat (antara tetua dengan keturunananya) (Aswidinnor et al., 2016). Nilai DGK lebih besar dari nilai DGU pada karakter (Tinggi tanaman, Jumlah anakan prokduktif, Jumlah anakan non produktif, Panjang malai, Jumlah gabah berisi dan berat 100 butir) menunjukkan karakter tersebut lebih banyak di kendalikan oleh gen-gen non aditif (Syukur, 2010).

Nilai duga daya gabung yang negatif menunjukkan bahwa galur-galur maupun kombinasi persilangan yang diuji berkontribusi terhadap penurunan keragaan karakter dan sebaliknya. Berdasarkan hasil analisis daya gabung empat tetua padi menggunakan metode Griffing II, menunjukkan dari ketujuh karakter yang diamati mempunyai efek DGU dan DGK yang positif. Hal ini menunjukkan semua tetua padi akan menghasilkan hasil yang bagus apabila disilangkan dengan sejumlah genotipe lain.

Karakter tinggi tanaman menunjukkan adanya perbedaan nyata di mana nilai dari DGK lebih besar dari pada DGU hal ini menunjukkan karakter tinggi tanaman ini lebih banyak di kendalikan oleh gen-gen non aditif. Dengan nilai F DGU $=15.81 *$ dan DGK= 18.54*. Nilai duga DGU untuk karakter tinggi tanaman menunjukkan bahwa tetua IPB memiliki efek daya gabung umum positif terbesar dibandingkan tetua lainnya. Hal ini menunjukkan IPB merupakan tetua yang akan menghasilkan tanaman padi yang tinggi dari tetua lainnya dengan nilai duga sebesar 113.8. Berbeda halnya dengan nilai duga DGK pada karakter tinggi tanaman yang menunjukkan bahwa hasil persilangan G11 x IPB mempunyai efek daya gabung khusus positif terbesar dibandingkan hasil persilangan lainnya. Hal ini menunjukkan G11xIPB merupakan hasil persilangan yang akan menghasilkan tanaman padi yang tinggi dari hasil persilangan lainnya dengan nilai duga sebesar 110.56. pernyataan pernyataan tersebut sesuai dengan pendapat Syahri dan Somantri (2013) bahwa penambahan tinggi tanaman pada tanaman padi dapat digunakan sebagai salah satu parameter pertumbuhan, tetapi pertumbuhan tanaman yang tinggi belum menjamin hasil yang diperoleh lebih besar.

Karakter jumlah anakan produktif ini menunjukkan adanya perbedaan nyata di mana nilai dari DGK lebih besar dari pada DGU. Hal ini menunjukkan bahawa karakter jumlah anakan produktif lebih banyak dikendalikan oleh gen-gen non aditif. Diketahui nilai F DGU $=10.93^{*}$ dan $\mathrm{DGK}=22.73^{*}$. Nilai duga DGU untuk karakter jumlah anakan produktif menunjukkan bahwa tetua G11 memiliki efek daya gabung umum positif terbesar dibandingkan tetua lainnya. Hal ini menunjukkan G11 merupakan tetua yang akan menghasilkan tanaman padi yang jumlah anakan produktifnya lebih banyak dari tetua lainnya dengan nilai duga sebesar 15. Berbeda halnya dengan nilai duga DGK karakter jumlah anakan produktif yang menunjukkan bahwa hasil persilangan G11xSP mempunyai efek daya gabung khusus positif terbesar dibandingkan hasil persilangan lainnya. Hal ini menunjukkan G11xSP merupakan hasil persilangan yang akan menghasilkan tanaman padi yang jumlah anakan produktifnya lebih banyak dari hasil persilangan lainnya dengan nilai duga sebesar 17. Menurut Cepy dan Wayan (2011), tinggi rendahnya pertumbuhan serta hasil tanaman dipengaruhi oleh 2 faktor yaitu internal yang meliputi karakter genetik atau turunan tanaman dan eksternal yaitu faktor lingkungan seperti iklim tanah dan faktor biotik. Perbedaan jumlah anakan masing-masing kultivar diduga karena pegaruh faktor-faktor tersebut. Pernyataan tersebut sejalan dengan hasil penelitian dari Anhar et al. (2016) yang menyatakan bahwa 
jumlah anakan dan tinggi tanaman yang berbeda dikarenakan setiap varietas memiliki karakter gen yang berbeda-beda.

Karakter jumlah anakan non produktif menunjukkan bahwa DGU tidak berbeda nyata dan DGK menunjukkan adanya perbedaan nyata di mana nilai dari DGK lebih besar dari pada DGU. Hal ini menunjukkan karakter jumlah anakan non produktif lebih banyak dikendalikan oleh gen-gen non aditif. Diketahui nilai F DGU $=0.21 \mathrm{~ns}$ dan $\mathrm{DGK}=4.31$ * Nilai duga DGU karakter jumlah anakan non produktif menunjukkan bahwa tetua IP memiliki efek daya gabung umum positif terbesar di bandingkan tetua lainnya. Hal ini menunjukkan IP merupakan tetua yang akan menghasilkan tanaman padi yang jumlah anakan non produktifnya lebih banyak dari tetua lainnya dengan nilai duga sebesar 2.4. berbeda halnya dengan nilai duga DGK karakter jumlah anakan non produktif yang menunjukkan bahwa hasil persilangan IPxSP mempunyai efek daya gabung khusus positif terbesar dibandingkan hasil persilangan lainnya. Hal ini menunjukkan IPxSP merupakan hasil persilangan yang akan menghasilkan tanaman padi yang jumlah anakan non produktifnya lebih banyak dari hasil persilangan lainnya dengan nilai duga sebesar 3. Muliarta et al. (2018) menyatakan bahwa anakan yang terbentuk pada tahap akhir fase vegetatif cenderung tidak mampu menghasilkan malai. Suaciati et al. (2012) menambahkan karakter kuantitatif pada tanaman padi dikendalikan oleh banyak gen, sehingga terbentuknya anakan produktif maupun non produkif tergantung pada karakter dari genotipe tanaman.

Karakter panjang malai menunjukkan adanya perbedaan nyata dimana nilai dari DGK lebih besar dari pada DGU. Hal ini menunjukkan karakter panjang malai lebih banyak dikendalikan oleh gen-gen non aditif. Diketahui nilai F DGU $=8.80 *$ dan DGK $=17$. 81*. Nilai duga DGU untuk karakter panjang malai menunjukkan bahwa tetua IPB memiliki efek daya gabung umum positif terbesar d bandingkan tetua lainnya. Hal ini menunjukkan IPB merupakan tetua yang akan menghasilkan tanaman padi yang panjang malainya lebih panjang dari tetua lainnya dengan nilai duga sebesar 30. Berbeda halnya dengan nilai duga DGK karakter panjang malai yang menunjukkan bahwa hasil persilangan IPBxIP mempunyai efek daya gabung khusus positif terbesar di bandingkan hasil persilangan lainnya. Hal ini menunjukkan IPBxIP merupakan hasil persilangan yang akan menghasilkan tanaman padi yang panjang malainya lebih panjang dari hasil persilangan lainnya dengan nilai duga sebesar 28.2. Panjang malai merupakan parameter yang menentukan tinggi rendahnya produktifitas suatu galur/varietas. Semakin panjang rata-rata panjang malai padi maka semakin banyak jumlah gabah yang dihasilkan, namun demikian tidak selalu memberikan hasil tinggi karena dipengaruhi presentase gabah isi dan gabah hampa. Hal ini sesuai dengan yang di kemukakan oleh De Datta (1981) bahwa jumlah gabah yang dihasilkan dari suatu malai yang terdapat dalam suatu rumpun belum seluruhnya menggambarkan banyaknya hasil yang diperoleh.

Karakter jumlah gabah berisi menunjukkan adanya perbedaan nyata di mana nilai dari DGK lebih besar dari pada DGU hal ini menunjukkan karakter tinggi tanaman ini lebih banyak dikendalikan oleh gen-gen non aditif. Diketahui nilai F DGU $=10.40 *$ dan DGK= 19.40*. Nilai duga DGU untuk karakter jumlah gabah berisi menunjukkan bahwa tetua IPB memiliki efek daya gabung umum positif terbesar dibandingkan tetua lainnya. Hal ini menunjukkan IPB merupakan tetua yang akan menghasilkan tanaman padi yang jumlah gabah berisinya lebih banyak dari tetua lainnya dengan nilai duga sebesar 207.6. Berbeda halnya dengan nilai duga DGK karakter jumlah gabah berisi yang menunjukkan hasil 
persilangan IPBxIP mempunyai efek daya gabung khusus positif terbesar dibandingkan hasil persilangan lainnya. Hal ini menunjukkan IPBxIP merupakan hasil persilangan yang akan menghasilkan tanaman padi yang jumlah gabah berisinya lebih banyak dari hasil persilangan lainnya dengan nilai duga sebesar 143. Presentase gabah bernas menentukan potensi hasil maksimum suatu varietas padi. Peningkatan hasil tanaman padi tiap rumpun diperoleh dari bobot butir, gabah per malai dan gabah bernas tinggi (Zen, 2007). Tingkat pengisian gabah atau gabah bernas ditentukan oleh hasil fotosintat (karbohidrat) dalam batang dan daun yang ditranslokasikan dan diakumulasi dalam gabah. Daun yang tegak, tebal, sempit dan hijau tua, serta tidak lekas luruh (tua) sangat dibutuhkan untuk pengisian gabah secara maksimum (Sudharmawan et al., 2008). Griffing (1956) juga menambahkan bahwa salah satu penyebab terbatasnya kemampuan genotype dalam menghasilkan gabah berisi dikarenakan belum seimbangnya translokasi fotosintat dari sumber (source) perima (pink).

Karakter jumlah gabah hampa menunjukkan adanya perbedaan nyata yang di mana nilai dari DGU lebih besar dari pada DGK. Hal ini menunjukkan karakter jumlah gabah hampa tanaman ini lebih banyak dikendalikan oleh gen-gen aditif. Dengan nilai F DGU $=15.13 *$ dan $\mathrm{DGK}=12.59 *$. Menunjukkan bahwa nilai duga DGU untuk karakter jumlah gabah hampa menunjukkan bahwa tetua IPB memiliki efek daya gabung umum positif terbesar dibandingkan tetua lainnya. Hal ini menunjukkan IPB merupakan tetua yang akan menghasilkan tanaman padi yang jumlah gabah hampanyanya lebih banyak dari tetua lainnya dengan nilai duga sebesar 31,2. Berbeda halnya dengan nilai duga DGK karakter jumlah gabah hampa yang menunjukkan bahwa hasil persilangan IPBxIP mempunyai efek daya gabung khusus positif terbesar di bandingkan hasil persilangan lainnya. Hal ini menunjukkan IPBxIP merupakan hasil persilangan yang akan menghasilkan tanaman padi yang jumlah gabah hampanya lebih banyak dari hasil persilangan lainnya dengan nilai duga sebesar 12.75. Menurut Hajoeningtijas (2013) salah satu faktor yang mempengaruhi pengisian gabah adalah kurangnya pati pada saat pengisian, yang disebabkan oleh kerebahan. Perbedaan jumlah gabah hampa per malai antar galur dapat disebabkan karena adanya perbedaan genetik antara genotipe (Muliarta, 2012). Menurut Sudharmawan (2008) bahwa jumlah gabah permalai yang banyak juga menyebabkan tingginya kehampaan.

Karakter berat 100 butir menunjukkan adanya perbedaan nyata dimana nilai dari DGK lebih besar dari pada DGU. Hal ini menunjukkan karakter tinggi tanaman ini lebih banyak di kendalikan oleh gen-gen non aditif. Diketahui nilai $\mathrm{F}$ DGU $=9.80 *$ dan $\mathrm{DGK}=$ 18.07*. Nilai duga DGU untuk karakter berat 100 butir menunjukkan bahwa tetua G11 memiliki efek daya gabung umum positif terbesar dibandingkan tetua lainnya. Hal ini menunjukkan G11 merupakan tetua yang akan menghasilkan tanaman padi yang berat 100 butirnya lebih berat dari tetua lainnya dengan nilai duga sebesar 31.2. Berbeda halnya dengan nilai duga DGK karakter berat 100 butir yang menunjukkan bahwa hasil persilangan G11xSP mempunyai efek daya gabung khusus positif terbesar di bandingkan hasil persilangan lainnya. Hal ini menunjukkan G11xSP merupakan hasil persilangan yang akan menghasilkan tanaman padi yang berat 100 butirnya lebih berat dari hasil persilangan lainnya dengan nilai duga sebesar 2.724. Menurut Yoshida. (1981), ukuran gabah menentukan potensi hasil. Sopa (2010) juga menambahkan bahwa gabah yang memiliki ukuran besar dan berat mengandung cadangan makanan lebih banyak dan ukuran embrionya lebih besar. 


\section{KESIMPULAN}

Pengaruh daya gabung umum dan daya gabung khusus untuk semua karakter yang di amati (tinggi tanaman, jumlah anakan produktif, jumlah anakan non produktif, panjang malai, jumlah gabah berisi, jumlah gabah hampa dan berat 100 butir) berbeda nyata, kecuali pada efek daya gabung umum karakter jumlah anakan non produktif menunjukkan berbeda tidak nyata. Hasil analisis daya gabung empat tetua bernilai positif,sehingga dapat dikatakan ke empat tetua akan mendapatkan hasil yang bagus apabila disilangkan dengan sejumlah genotipe lain.

\section{DAFTAR PUSTAKA}

Aliu, S., S. H. Fetahu, A. Salillari. 2008. Estimation of heterosis and combining ability in maize (Zea mays L.) for ear weight (ew) using the dialel crossing method. Latvian J. Agron. 11:7-11.

Anhar, R., H. Erita dan Efendi. 2016. Pengaruh Dosis Pupuk Urea Terhadap Pertumbuhan dan Produksi Plasma Nutfah Padi Lokal Asal Aceh. Jurnal Kawista. 1(1); 30-36

Arraudeau MA., Vergara BS. 1992. Pedoma Budidaya Padi Gogo. Gani A, Zaini Z, Hamzah Z, penerjemah; Bogor (ID): Badan Penelitian dan Pengembangan Pertanian, Balai Penelitian Tanaman Pangan Sukarami. Terjemahan: A Farmer's Primer on Growiing Rice

Aswidinnor H, Willy B. Suwarno, Desta Wirnas, Yudiwanti We Kusumo. 2016. Teknologi Produksi Optimum (IPB-Prima) Padi Varietas IPB 3S dan IPB 4S. Departemen Agronomi Dan Hortikultura. Fakultas Pertanian. Institut Pertanian Bogor.

Badan Litbang Pertanian. 2007. PetunjukTeknis Lapang Pengelolaan Tanaman Terpadu (PTT) Padi Sawah Irigasi. Departemen Pertanian. Jakarta.

Badan Pusat Statistik. 2016. Produksi Padi Menurut Provinsi (Ton) 1993-2015. http://www.bps.go.id/linkTabelkDinamis/view/id/865 [20februari 2018]

Chapman and Hall. 1985. The Science of Animal that Serve Humanity. 3th Edition. McGraw-Hill Book Company, Inc. New York

De Datta SK. 1981. Principle and Practice of Rice Production. New York (US): Jhon Willey and Son.

Fatimaturrohmah S., M Indarastuti A.R., Sogianto A., dan Damnhuri. 2016. Uji Daya Hasil Lanjutan Berapa Genotipe Padi (Oryza sativa L.) Hibrida di Dataran Medium. Produksi Tanaman. 4 (2): 129-136

Griffing, B. 1956. Concept of general and specific combining ability in relation to diallel crossing system. Aust. J. Biol. Sci. 9(4): 463- 493

Hajoeningtijas, O.D., dan Agus Mulyanti Purnawanto. 2013. Keragaman Padi Gogo Lokal di Kabupaten Banyumas Jawa Tengah. Fakultas Pertanian Universitas Purwokerto. Agritech: Vol. XV No. 22013.

Herawati W. D. 2012. Budidaya Padi. Javalitera. Yogyakarta.

Muliarta, I.G.P., Sutresna I.W., Yurnawati. 2018. Uji Daya Hasil Galur Generasi F3 Padi Beras Merah (Oryza sativa L.). Jurnal sains Teknologi \& Lingkungan Vol. 4 (1): 7382 
Singh, R.K. and B.D. Chaudar y. 1979. Biometrical Method in Quantitative Genetic Analysis. New Delhi: Kalyani Publisher.

Sopa, E. M. 2010. Pengaruh Dosis Radiasi Sinar Gamma terhadap Pertumbuhan dan Hasil Tiga Kultivar Padi Lokal Rawa Lebak Bengkulu. Universitas Bengkulu.

Syahri dan R.U. Somantri. 2013. Respon Pertumbuhan Tanaman Padi terhadap Rekomendasi Pemupukkan PUTS dan KATAM Hasil Litbang Pertanian di Lahan Rawa Sumatra Selatan. Jurnal Lahan Suboptimal. 2 (2): 170-180.

Syukur, M., Sujiprihati, S., Yunianti, R., \& Undang. 2010. Diallel analysis using hayman to study genetic parameters of yield components in pepper (Capsicum annum L.). Hayati Jurnal of Bioscience, 17(4), 183-188.

Syukur, M., Sriani Sujiprihati, dan Rahmi Yunianti. 2012. Tehnik Pemuliaan Tanaman. Penebar Swadaya. Jakarta.

Suciati E.C., Nasrullah., Sutardi. 2012. Uji Daya Hasil Delapan Galur Harapan Padi Sawah (Oryza sativa L.). Penelitian Pertanian Tanaman Pangan.: 75-83

Sudharmawan A.A. K., I.G.P. Muliarta, I.W. Sudika, Sanasih. 2007. Perakitan Varietas Unggul Padi Beras Merah Tipe Ideal Melalui Perkawinan Interspesifik Padi Beras Merah Ras Cere dan Bulu Kultivar Local NTB. Laporan Penelitian Hibah Bersaing Tahun 1.

Yoshida, S. 1981. Fundamentals of Rice Crop Science.The International Rice Researce Institute, Los Banos, Laguna, Philippines.

Zen, S. 2007. Stabilitas Hasil Galur Baru Padi Sawah Preferensi Konsumen Sumatra Barat. Jurnal Aritrop 26 (1):1-5 